\title{
The Story of the Bungalow Alice Springs, 1914-1929: A Decolonised, Creative Non- Fictive Treatment with a Focus on the Women and Children
}

\author{
Linda Wells
}

Deakin University, Geelong, Vic.

\begin{abstract}
The Bungalow began as a tin shed built in 1914 in Alice Springs to house Topsy Smith and her children, of mixed Indigenous and European heritage, whose father had recently died. Over the years that followed many more children with Indigenous mothers and European fathers were taken from their families and brought to live at the Bungalow until about 60 children were growing up there and two more sheds were built. Traditional historiographic methods of research and writing have been combined with the techniques of creative non-fiction, with an overarching focus on decolonisation, to foreground women and children in a story that brings the first Bungalow to life.
\end{abstract}

Topsy Smith was a First Nations Arabana woman, initially from central South Australia. Her husband and the father of her children was Welshborn Bill Smith. For 25 years the Smiths lived at the goldfields at Arltunga, 100 kilometres from Alice Springs, and had 10 children, three of whom died in infancy. In 1914 Bill died, prompting Topsy to travel into Alice Springs with six children, one more on the way, and a sizeable herd of goats. ${ }^{1}$ In 1914 the town was an isolated outpost built on land known to its Arrernte custodians as Mparntwe. It comprised three houses, three

1 National Archives of Australia (NAA): Department of Home and Territories, Central Office; Correspondence files, annual single number series, 01 Jan 1890 - 31 Dec 1969; A1, 1930/1542; 'Visit of Sir Baldwin Spencer to Northern Territory re natives at Alice Springs' [Stuart and Hermannsburg mission station] 1921-1924, 4. 
stores, a hotel and a police complex. ${ }^{2}$ It was officially known until 1933 as Stuart, in honour of the first colonial representative who managed to pass through that country, although Alice Springs was the town's nickname from the outset. ${ }^{3}$ Most of the colonial activity in the region took place in a radius of many hundreds of kilometres and included cattle farming, mining, mission work, and communications based around the repeater stations of the Overland Telegraph Line.

When Topsy and the children arrived in town, Sergeant Stott, the local policeman and 'sub-protector of Aborigines', erected a tin shed across the road from the police station for them to live in. The tin shed became known as the 'Bungalow for half-castes'. Over the years that followed, many more children of mixed heritage were brought to live at the Bungalow, until eventually there were about 60 children growing up there, cared for by Topsy and another Aboriginal mother who had turned up with her children. They were provided with rations by the police. ${ }^{4}$

The other central figure in this story is Ida Standley. She was a single white woman and mother of four grown-up children who had moved to Alice Springs as the town's first schoolteacher, just weeks prior to the arrival of the Smiths. Although initially recruited to teach the children of the white settlers, she was permitted to teach the children of the Bungalow as well, providing it was done separately. Ida soon took on extra paid duties as the matron of the Bungalow. ${ }^{5}$ She stayed until 1929 and was one of two women across Australia that year to be awarded an Order of the British Empire, for her services to education in Central Australia. ${ }^{6}$

2 Kate Holmes, Alice Springs: The Original 104 Lots (Darwin: National Trust of Australia, 1990).

3 Alice Spring was a seemingly permanent waterhole in the river a couple of kilometres to the north of the town, beside the telegraph station. It was named after Lady Alice Todd of Adelaide, wife of Charles, who was employed to oversee the construction of the Overland Telegraph Line. Lady Alice never made it to Central Australia. The waterhole was not a spring. Therefore, the town is named after a woman who never went there and a spring that did not exist. It was pluralised at some stage, for no apparent geographic or historic reason.

4 National Archives of Australia (NAA): Department of Home and Territories, Central Office; Correspondence files, annual single number series, 01 Jan 1890 - 31 Dec 1969; A1, 1930/1542; 'Visit of Sir Baldwin Spencer to Northern Territory re natives at Alice Springs' [Stuart and Hermannsburg mission station] 1921-1924, 6.

5 Ibid., 4.

6 'Ida Standley', Department of the Prime Minister and Cabinet, Australian Government, honours. pmc.gov.au/honours/awards/1085873. 
I am an Australian of European descent, born and raised on Wurundjeri lands to the east of Melbourne. I then lived in Alice Springs on Arrernte country, and nearby Warlpiri and Anmatyerre lands, for nearly 30 years. I had a relationship with a Warlpiri man and together we had our daughter. As a long-term schoolteacher, history practitioner and proud mother of a young woman with both Indigenous and European heritage, the story of the original Bungalow piqued my interest. It seemed to me a foundational story of education and early intercultural relations, pivotal to the social foundations of the town as the original arterial roads and planning documents were to its material establishment.

The Bungalow, from 1914 to 1929, formed the basis of my doctoral research. It is through those years that Ida Standley and Topsy Smith worked together to run the place with Sergeant Stott as the overseer. The Bungalow did continue after that, in other locations and under different administrations, but it is a historic and literary examination of the original Bungalow and its people that is the subject of my inquiry.

I explored it historically, through the thousands of original documents pertaining to this time and place that are held in government archives around the country. I supplemented that research with four oral history recordings, from the Northern Territory Archives Service in Alice Springs, that were made with people, in the senior years of their lives, who had grown up in the Bungalow. I also engaged with living descendants of residents of the Bungalow, sought permission to conduct this research and included their family memories in my narrative. I further explored the story of the Bungalow and its context autoethnographically, living in Alice Springs for many years and reflecting critically on my observations. I then used techniques of creative non-fiction to capture the spirit of the time and place in which the Bungalow was set, as well as demonstrate the connections between the past and the present.

In this article I outline the approach I took to the research and writing of the story of the Bungalow using a practice-led methodology with decolonising intent. I also discuss the multi-genre style of my historical writing and its relevance to a work of post-colonial creative non-fiction that brings women, children and intercultural relations to the forefront, making them the focus of this story from the frontier. Some samples from work of creative history are included to demonstrate the outcomes of my research. 


\section{Decolonising Research and Writing Practices}

Australia's colonial government, judicial system, education and its knowledge construction factories were built on the graves of Indigenous Australian systems, on the assumption that the 'race' of Indigenous nonhumans had no such systems in place prior to the invasion. ${ }^{7}$

Australia's history has similarly been dominated, since the earliest days of colonisation, by narratives that focus on the 'peaceful tale of the progress of White Australian society'. ${ }^{8}$ This 'peaceful tale' saw the separation of Indigenous and colonial histories and the presentation of the land's first people as hostile, primitive and barbaric. ${ }^{9}$ As well as being an overwhelmingly white story, the account of the past that has been constructed by the dominant social group in Australia has been 'overwhelmingly a masculine story' in which 'European women were an absence, indigenous women a cipher; neither had status as autonomous subjects, neither had agency'. ${ }^{10}$ The decolonisation of Australian history requires us to view the narratives of our history from other than the dominant colonial perspectives.

The decolonisation of research and writing similarly requires us to view the paradigms and practices of research from the perspectives of First Nations people. Research and its designs need to contribute to the selfdetermination and liberation struggles of Indigenous people, as defined and controlled by their communities. ${ }^{11}$

7 Lester Irabinna-Rigney, 'Internationalization of an Indigenous Anticolonial Cultural Critique of Research Methodologies: A Guide to Indigenist Research Methodology and its Principles', Wicazo Sa Review, 14, no. 2 (1999): 112.

8 Lyndall Ryan, 'Review of Richard Broome, Aboriginal Australians: Black Response to White Dominance 1788-1980 and Henry Reynolds, The Other Side of the Frontier: Aboriginal Resistance to the European Invasion of Australia', Australian \& New Zealand Journal of Sociology, 19, no. 2 (1983): 338-42.

9 Adele Wessell, “We Will Show the Country": Bringing History to Life', M/C Journal, 20, no. 5 (2017), journal.media-culture.org.au/index.php/mcjournal/article/view/1299.

10 Patricia Grimshaw, 'Women, Gender, Sexuality, and Colonialism's Culture', Pacific Studies, 20, no. 1 (1997): 123-29; Thomas J. Prasch, 'Orientalism's Other, Other Orientalisms: Women in the Scheme of Empire', Journal of Women's History, 7, no. 4 (1995): 174-89.

11 Irabinna-Rigney, 'An Indigenous Anticolonial Cultural Critique of Research Methodologies', 109-10. 
Indigenist research and writing practices are culturally safe and respectful. They show a recognition of Indigenous worldviews, knowledges and realities as distinctive and vital to existence and survival. They honour social mores as essential processes through which Indigenous people live, learn and situate themselves in their own lands and when in the lands of other people. They emphasise the social, historical and political contexts that shape people's experiences, lives, positions and futures. They also privilege the voices and experiences of Aboriginal people and their lands. ${ }^{12}$

There are many protocols and practices non-Indigenous researchers and writers can adopt in the spirit of indigenist research and the decolonisation of research and writing. ${ }^{13}$ Jackie Huggins notes that for non-Aboriginal people to write about Aboriginal people, having a respect for and knowledge of Aboriginal culture, history, social issues and what was happening to Aboriginal people in the era in which they are being written about is imperative. ${ }^{14}$

Ambelin Kwaymullina, Blaze Kwaymullina and Lauren Butterly suggest that the first priority for scholars working with Indigenous material is to begin with the texts of Aboriginal Elders, communities and scholars. ${ }^{15}$ A key text I engaged with in this regard is Gordon Briscoe's memoir Racial Folly: A Twentieth Century Aboriginal Family. Briscoe's mother was removed from her family and taken to the Bungalow in 1927. She gave birth to Gordon at the Bungalow in 1935, after it had been moved to the Alice Springs Telegraph Station. In Racial Folly, Briscoe has drawn on his own life experience and family history as well as those of his contemporaries, and juxtaposed these with the official Indigenous Affairs policies and

12 Karen Martin and Booran Mirraboopa, 'Ways of Knowing, Being and Doing: A Theoretical Framework and Methods for Indigenous and Indigenist Research', Journal of Australian Studies, 27, no. 76 (2003): 203-14.

13 Jackie Huggins, 'Respect v Political Correctness', Australian Author, 26, no. 3 (1994): 12-13; Martin and Mirraboopa, 'Ways of Knowing'; Irabinna-Rigney, 'An Indigenous Anticolonial Cultural Critique of Research Methodologies'; Martin Nakata, 'The Cultural Interface', Australian Journal of Indigenous Education, 36, no. S1 (2007): 7-14; Lynore K. Geia, Barbara Hayes and Kim Usher, 'Yarning/Aboriginal Storytelling: Towards an Understanding of an Indigenous Perspective and its Implications for Research Practice', Contemporary Nurse, 46, no. 1 (2013): 13-17.

14 Huggins, 'Respect v Political Correctness', 12.

15 Ambelin Kwaymullina, Blaze Kwaymullina and Lauren Butterly, 'Living Texts: A Perspective on Published Sources, Indigenous Research Methodologies and Indigenous Worldviews', International Journal of Critical Indigenous Studies, 6, no. 1 (2013): 1-13. 
programs of the late nineteenth and into the twentieth centuries. ${ }^{16}$ After reading his story, I made phone contact with Gordon and his son Aaron to discuss my project and invite any further contribution.

Another key text that has informed my project is The Man from Arltunga: Walter Smith Australian Bushman by Dick Kimber. ${ }^{17}$ This is a biography based on interviews with Walter (1898-1990), the eldest of Bill and Topsy's children, in the later years of his life. Walter was 17 when his father died and the family moved to Alice Springs. The Man From Arltunga offers intimate insights into Walter's own story, his family background as well as the social and political context of Central Australia in the early years of the twentieth century. Walter's story is not one of binary opposites and divisions to which Australian history has so often been reduced; rather of a man who spoke many First Nations and other languages and engaged with people across a rich Central Australian intercultural landscape.

The oral history recordings of people who grew up in the Bungalow offer insights into conditions that at times confirm information from colonial sources and, at other times, fill in gaps and silences. Other primary sources that are held in government archives offices across Australia and provide access to Indigenous people's voices from the Bungalow era include letters and recorded testimonies from court hearings. In my written work I quote directly from that material where that seems most relevant, to privilege Indigenous voices and to minimise interfering with the original meanings of what people have said.

Karen Martin and Booran Mirraboopa refer to 'terra nullius research'that is, presenting Indigenous people as objects of curiosity and subjects of research, to be seen but not asked, heard or respected. ${ }^{18}$ I strive to not operate in this way. I contacted several people whose ancestors were inmates of the Bungalow, consulted them about my project and invited them to tell their stories. Each person I contacted was enthusiastic about the project and either met with me where possible or communicated with me by phone and email, discussing the experiences of their ancestors.

16 Gordon Briscoe, Racial Folly: A Twentieth Century Aboriginal Family (Canberra: ANU E Press, 2010). doi.org/10.22459/RF.02.2010.

17 R. G. Kimber, Man From Arltunga (Western Australia: Hesperian Press, 1996).

18 Martin and Miraboopa, 'Ways of Knowing', 203. 
I introduced myself to each interviewee from the outset, outlining my subject position and experiences of living and working in Central Australia. Positioning myself in this way accords with both Huggins's point that 'detached observer status is not advisable' and Martin and Mirraboopa's assertion that introducing oneself to other Indigenous people is to provide information about one's cultural location, so that connection can be made on political, cultural and social grounds. ${ }^{19}$ As noted by Lenore K. Geia, Barbara Hayes and Kim Usher, 'most Indigenous people in Australia prefer to share small yarns of introduction, and enquiry of their personal wellbeing and the country they belong to on first encounter with a stranger'. ${ }^{20}$

The interviews, in the style of yarning, were relaxed and informal discussions: 'a journey both the researcher and the participant share as they build a relationship and visit topics of interest to the research. ${ }^{21}$ I presented my findings and listened to and recorded what the interviewees told me. Each interviewee also shared relevant documents from their own files, including newspaper clippings, family letters and photos. Together we speculated about what it must have been like for their ancestors at the Bungalow, the ongoing effects of what went on, and why things happened in the ways they did. I have kept participants informed about the progress of the project. As per the initial agreements we made, and in line with university ethics approval, I provided them with drafts of any material I wrote about their ancestors and sought their responses to the writing. Through this process, changes have been made to early drafts of my writing and final approvals granted.

\section{The Multi-Genre Approach}

I set out to research and write a history of the Bungalow and the context in which it existed. My aims, which emerged and continued to morph through the life of the project, were to tell a story, drawing on my positionality, ethical framework and writing skills, that captures the time, space and place of the Bungalow. This literary work would demonstrate that what went on a century ago is alive today in Central Australia and beyond. It would also appeal to a broad general readership. As my

19 Ibid., 204; Huggins, 'Respect v Political Correctness', 13.

20 Geia, Hayes and Usher, 'Yarning/Aboriginal Storytelling', 16.

21 Ibid., 15. 
research and writing proceeded, it became apparent that no single literary style held the key. To narrate the story in accordance with my aims, I found myself engaging with a range of critical and literary techniques that included speculative biography, archival poetics, fictocriticism and autoethnography along with more traditional, referenced history.

\section{Speculative Biography: Lives as They May Have Been Lived}

Bain Attwood has observed that oral histories can be used to 'bring the stories to life of people whose pasts have been hidden by the modern discipline of history's conventional practices'. ${ }^{22}$ The same can be said of speculative biography. As such, it plays a role in democratising history. Speculative biography also offers tools for the creation of a palpable sense of time and place or, in the words of British author Andrew Miller, 'of putting the blood and bone back into the inquiry process while retaining an allegiance to the evidence'. ${ }^{23}$

Of the three central adult figures of my study, the one who has the greatest presence in the thousands of records, letters, government correspondence, visitors' book entries, journals and reports and newspaper articles is the white man Robert Stott. The person with the second-largest presence in all those documents is the white woman Ida Standley. The person of whom there is the least in the archives is the First Nations woman Topsy Smith.

Despite her significant presence at the Bungalow and the great contribution she made (which we know about from other sources), Topsy appears in only one archived document. It is a report, from 1923, commissioned by the federal government and compiled by anthropologist Baldwin Spencer. In the report Spencer notes that:

22 Bain Attwood, 'Aboriginal History, Minority Histories and Historical Wounds: the Postcolonial Condition, Historical Knowledge and the Public Life of History in Australia', Postcolonial Studies, 14, no. 2 (2011): 171-86.

23 Andrew Miller, 'Personalising Ethnography: On Memory, Evidence, and Subjectivity. The Writing \& Learning Journey', New Writing: The International Journal for the Practice and Theory of Creative Writing, 5, no. 2 (2008): 89-113. 
In 1914, after the death of a miner with whom she had been living at Arltunga, a native woman named Topsy Smith came to Stuart bringing with her seven (7) half caste children ... In 1915 the Administrator, after visiting the Bungalow, authorised the extension of the building to accommodate half castes from outside districts, Topsy Smith still remaining in charge. ${ }^{24}$

And:

At night-time Topsy Smith takes charge, but each evening the Matron comes and sees that all the children are in. There have been occasions on which requests have been made to Topsy Smith for girls, and attempts have been made at night to take them away, when she had to seek the assistance of the matron and Sergeant Stott. ${ }^{25}$

Four references in two paragraphs and a couple of appearances in group photographs seems to be the sum of Topsy's presence in the archives. In a few other documents she is mentioned in such dismissive and dehumanising ways that we cannot even know for sure they are about her. For example, in a series of scathing articles about the Bungalow that appeared in the press of Australian capital cities in 1924 it was reported that:

The cooking accommodation consists of a sort of sentry box affair, with an ordinary stove in it which would send the ordinary housewife on strike if she were asked to cook for a family of ten on it. The cooking hutch is open to the winds that blow; the cook and housekeeper is an old black gin. ${ }^{26}$

'An old black gin.' Presumably that was a reference to Topsy. And if it was not, then Topsy, the most constant adult presence at the Bungalow, every day and night for 15 years, was not mentioned in this reporting at all. As such, Topsy Smith is an 'unusual' rather than 'usual suspect' of history and therefore an ideal subject for speculative biography. ${ }^{27}$

\footnotetext{
24 National Archives of Australia (NAA): Department of Home and Territories, Central Office; Correspondence files, annual single number series, 01 Jan 1890 - 31 Dec 1969; A1, 1930/1542; 'Visit of Sir Baldwin Spencer to Northern Territory re natives at Alice Springs' [Stuart and Hermannsburg mission station] 1921-1924, 4.

25 Ibid., 6.

26 M. H. Ellis, 'Grave Scandal at Alice Springs', Daily Telegraph, 8 October 1924, 1.

27 Kiera Lindsey, 'Practicing the Past: A Manifesto', keynote address at the Speculating on Biography: Exploring the Boundaries of Biographical Writing Symposium, Central Queensland University, Noosa, 26 October 2018.
} 
Kiera Lindsey is a historian and writer of speculative biography. When researching the story of a subject whose archival footprint is minimal, Lindsey looks for a 'spine source' that has sufficient historical legitimacy and immediacy to be compared with other sources, in the search for recurring themes and overlapping clues. ${ }^{28}$ She then reads across other sources to look for patterns and clues and build up a deeper, richer picture of her subject.

My 'spine source' for Topsy became the information provided about her in the oral histories of the 1980s and 1990s. Using them as my starting point, I then 'read across other sources' to build up a deeper, richer picture, not only of Topsy and her position in the Bungalow, but also of her position in Central Australian society. These sources included interviews I conducted with descendants of Bungalow survivors, particularly Topsy's granddaughter Christine Donnellan; the biography of Topsy's son Walter; and the original archival material. Alistair Paterson's historical archaeology research into early cultural contact on the Arabana Lands provided further valuable background into the political, social and environmental backgrounds of the world into which Topsy was born and raised. ${ }^{29}$

Topsy grew up on the Arabana Lands. At some stage, Welsh-born Bill Smith, of a similar age to Topsy, came into her life. Perhaps he was passing through Arabana Land on his way north to the goldfields, or perhaps he had been working in the region. Either way, Bill and Topsy met around 1890 and formed a partnership. They travelled a route known officially as 'the Track' that took them to the goldfields at Arltunga. I have drawn on published accounts of the Track from around that time, recollections from Bill and Topsy's descendants and my own encounters in the country they traversed, to craft a chapter about their journey together to the goldfields. It begins with a preface that flags the speculative nature of the piece:

Up the Track

Topsy was leaving the place of her childhood. Bill was continuing on his nomadic way; from Wales, to the shores of Australia, and now into its heartland. From the occasional published accounts of the Track, recollections from their descendants and my own encounters in that country, I have reimagined the journey of Bill and Topsy. ${ }^{30}$

28 Ibid.

29 Alistair Paterson, The Lost Legions: Culture Contact in Colonial Australia: (Lanham, MD: Altamira Press, 2008).

30 Details of 'the Track' from Graeme Bucknall, Pioneers of the Old Track: Oodnadatta Alice Springs, 1870-1929 (Darwin: Northern Territory Library Service, 1990); Mayse Young with Gabrielle Dalton, No Place for a Woman: The Autobiography of Outback Publican, Mayse Young (Australia: Pan MacMillan, 1991). 
They headed north, up The Track.

My wife, Bill called her proudly, with no regard for what anyone else might have thought. She was strong and skilled and sweet.

My husband, Topsy called him. He was kind and determined with a song in his voice.

There were things that mattered and the colour of one's skin wasn't one of them, even if others tried to make it matter.

The pair knew about The Track; what to look and look out for.

It was the path that Topsy's ancestors on the Arabana side had set as a trading route.

The track trod by Stuart with his horses and men.

The Track that the Overland Telegraph Line ran followed.

The obvious route, the one that followed water.

There was traffic enough. With the gold rush going on, it was never long before someone else passed by. More of them heading north than south. Most of them with just what they could carry or push in a wooden barrow. Some of them whistling under the desert sky. Others trudging so hard you wondered if you'd have to bury their bones around the bend. The occasional train of camels trekking, north or south. A few, like themselves, with horse and buggy.

Crunching over stony plains.

The sun beating down.

Flies and prickles. Glare and wind. The heat throwing mirages in the distance.

Bill and Topsy had some supplies they'd brought with them; flour, tea and the like. They supplemented that with food they found along the track: a goanna roasted in the coals of the campfire, some berries Topsy picked from a bush.

On day three, with the sun dropping low in the western sky, they arrived at the riverbed they'd had in their line of vision all afternoon. It was a sprawling expanse of sand dotted with river gums.

'Two big waterholes,' Bill nodded. 'This must be Bloods Creek.' 
Topsy grinned and dropped into the cool sand. 'Mwenangkenh tula,' she said, identifying the place by its original name. 'Let's camp here.'

On Day 4 the track converged briefly with the Telegraph Line at the Charlotte Waters Telegraph Station. Topsy had only seen a few such constructions in her life and this, along with its twin at Pangki Warruna, were the largest. Bill had seen many and had grown up looking into them, in his homeland and then in Adelaide.

'White fella building,' Topsy announced and Bill laughed. He enjoyed Topsy's perspective. They passed the whitefella building on their left.

The stony plains gave way to soft, sandy floor as The Track entered the floodplains of the vast Finke River system. It brought welcome relief for horse and humans. More food, more shade, another welcome camping spot.

At night they heard the dingoes howl.

The next morning they came across a simple homestead and a shepherds tending to flock.

'You gotta walk along creek, riiight along, big walls too much,' he said, pursing his lips to indicate the great red gorge up ahead. 'Come up on bank, other side ... You be right,' he added, perhaps at their apprehension. Looking towards this young woman on the move but without making eye-contact he asked, 'Who your mob?'

'Arabana,' she replied. 'Mary my mum.'

He raised his eyebrows knowingly then indicated Bill. 'Dis your wati?'

'Yeah, he my husband.'

The man smiled. 'Good luck to you,' and went back to what he was doing.

The thick river sand was hard going so they stopped halfway to boil the billy and rest the horse; rock walls towering on either side.

Ghost gums and wild figs grew on the slopes of the ranges. A soft breeze blew. A flock of red-tailed black cockatoos screeched overhead. 
Topsy, sitting on the sand and gazing up, watched until they were out of sight. 'We're on the right track,' she told Bill.

He smiled and leaned over to wipe the strands of hair from her face.

It was a relief when they finally left the thick sand and walked on firm ground for a while.

At the base of a sandhill, there was a grave with no name.

'Perished,' Topsy said. 'He didn't know about the water up ahead.' Sure enough, just a few hundred metres around the sandhills from the grave, was a small gorge shaped like a horseshoe with a waterhole at its base. The horse had gulped it up and Bill and Topsy filled their bags. The cattle station was up to the left.

They wound their way up through the gorge, where the river gums made a rim of green along the creek. Then it was back onto river flats until they reached the Depot Sandhills.

A sea of shifting sand dunes of powdery red sand. It felt like it would never end. The wind howled relentlessly, erasing the prints of those who'd gone before. They made it up, step by step, guided by the Telegraph Line. The horse needed coaxing and in places Bill and Topsy laid down a mat of spinifex grass to ease the buggy wheels over.

Finally, they looked out and down to riverbed again; a snaking path of white sand lined with trees. They tumbled down into its shade to stretch and rub each other's aching muscles. Rest over, they continued, through one river crossing after the next; stopping to eat, camp and dig for water.

Beyond the Ooraminna Range they reached a fork in the road; Alice Springs or Arltunga? More of the same stretched either way but they knew their destination was almost within range. Bill hooted and Topsy laughed.

On day fifteen they passed through the hilly outskirts of the settlement and pulled up in the village that had grown up on Eastern Arrernte country. It was abuzz with hope from recent finds.

The rhythms Bill and Topsy had developed on their journey became the refrain of the life they went on to build together at Arltunga. ${ }^{31}$

31 Linda Wells, 'Living in Tin: The Bungalow Alice Springs, 1914-1929' (PhD thesis, Deakin University, 2020), 31-34. 


\section{Archival Poetics}

Archival poetics is an affective response to the limitations of the archives; their ideological underpinnings, silences, gaps, biases and the arrogance of assumed objectivity. It emerged for me, through this project, as an intuitive act, as it was for Natalie Harkin in response to accessing her own family's state archival records. ${ }^{32}$ Archival poetry, as described by Harkin, is a slow, unfolding, situated poetic method that emerges from the immersion and the telling that comes from data collection from multiple archival sources. ${ }^{33}$ Archival poetic approaches ground themselves in historical events and facts, but do so self-reflectively. They remain 'sensitive to the flow between fact and fiction in [their] depiction of tensions between methods of documentation that purport to be objective or journalistic and those that are framed ... as subjective or affective'. ${ }^{34}$ As such, large parts of my creative work could be considered archival poetics.

I composed one specific piece of archival poetry in response to the dehumanising and objectifying language of miscegenation that appears with monotonous regularity through Australian colonial documents across decades. No matter how often I came across those words during the course of my research, I felt fresh disgust each time. In the following dedicated piece of archival poetry, I plucked words and phrases straight out of the Central Australian documents I was reading, from 1910 to 1930, then arranged them in poetic form. It felt like an act of protest, to make those words stand on their own and allow their hideous absurdity to speak for itself:

\section{ARCHIVAL PORTRAIT OF HALFCASTERY ${ }^{35}$}

\section{The colour problem}

A most difficult problem

What shall be done with the half-castes?

Intermingling of the white blood with that of the untutored savage

Little outcasts of society

A kind of helot class

32 Natalie Harkin, “I Weave Back to You”: Archival-Poetics for the Record' (PhD thesis, University of South Australia, 2016); Natalie Harkin Archival-Poetics (Sydney: Vagabond Press, 2019).

33 Harkin, "I Weave”, 14.

34 Rebecca Macmillan, 'The Archival Poetics of Claudia Rankine's Don't Let Me Be Lonely: An American Lyric', Contemporary Literature, 58, no. 2 (2017): 173-203.

35 Poetry composed of lines and phrases from government documents pertaining to Central Australia between 1910 and 1930, held in the National Archives of Australia. 


\section{The tragedy}

Backward children and adults

Much inferior to the full-blooded aboriginals

\section{The solving of the half-caste problem}

Enquire into the half-caste problem

Report on the half-caste question

Enquire into the half-caste problem

Enquire into the half-caste problem

Report on the Half Castes and Aboriginals of the Southern

Division of the Northern Territory

\section{Proposals for the housing, care and instruction of half-castes in the Alice Springs District}

Training of the half-castes

A home for half-castes

A suitable building for half-castes

A kind of preparatory home and school for the very young

half-castes

A self-supporting home for all half and three-quarter caste

females

Protection of half-caste native girls

Under reasonable conditions of seclusion from the rest of the community

Complete segregation

They should be treated as children in law

Unless they are educated and Christianised

All Territory half-castes and possibly those of the Northern part of South Australia sent to southern orphanages

Some of the most intelligent half caste youths

Raise them to the status of their white parents

Positions in the ordinary life of the community

\section{Removal from the bush}

Fully fifty half-castes still remain to be collected in Central

Australia

The earlier this is done the better for them

The bush blacks

The natural tendency, unfortunately, is to drift to the Aboriginal

Revert to bush conditions of life

The half-caste of $50 \%$ or more aboriginal blood, no matter how carefully brought up, will drift back to the aboriginal

Wild bush brothers

And it will take some time to eradicate 


\section{Removal from the town}

It was necessary to remove the half-castes from the town It was essential that the half-castes should be removed from the town of Stuart

\section{Gross immorality}

Malicious scandal

Infamous debauchery

Lubras

Concubines

Black gins

Half-caste progeny

A number of the surnames were identical with those of settlers in the Territory

Out of the 40 or 50 children in the Bungalow, only about 4 are being maintained by their fathers

Prevent the employment of Aborigine and half-caste females by white men unless under the care and protection of a respectable married white woman

The increase of white women in the community shall greatly assist in solving the problem

\section{Crossbreeds}

Three-quarter caste aboriginals

Half-caste aboriginals

Quadroons

Octaroons

There are cases here where half caste girls have three quarter caste children

Seven half-caste women with thirteen quadroon and octaroon children

Seven quadroons under thirteen years of age

Four quadroon women with three octaroon children

Quadroons and octaroons under ten or twelve years of age

\section{A half-caste from Central Australia}

Shows no indications of aboriginal blood

Eventual absorption in the white population

What a valuable asset can be made of what is now a difficult problem 


\section{An eminent authority on the aborigines of Australia}

Chief protector of Aborigines

Sub Protector of Aborigines

In dealing with these people one is often perplexed and

the longer you are with them the better you realise how little you understand them ${ }^{36}$

\section{Fictocriticism}

Fictocriticism, as scholar and author Noel King notes, is a flowing together of theory and narrative in which the 'theory can't exist without telling little narrative stories'. ${ }^{37}$ 'Little' would seem to be an understatement here. Nevertheless, King's assertion highlights the symbiosis between theory and narrative that is the essence of fictocritical work. The stories 'perform' the theory and the theory in turn provides foundation for the stories. Lying between conventional scholarly treatments and fiction, or, as King puts it, 'deliberately blurring the distinction between literature and literarycritical commentary' is the key defining feature of the genre. ${ }^{38}$ It is, in short, a blending of the 'fictional' and the 'critical'.

In his fictocritical work 26 Views of a Starburst World, Ross Gibson applies what he calls a 'compositional approach' to analyse the notebooks of William Dawes, government astronomer with the First Fleet, and his relationships with Eora people in the early days of settlement at Sydney Cove. ${ }^{39}$ Of this style, Gibson explains, that to account for what Dawes learned, 'we need a mode of writing-roundabout, relational, a tad restless and unruly — that can bring us toward some states of mind that are not biographical, psychologically focussed or conclusive'. ${ }^{40}$ Here Gibson is highlighting the interconnection between the style and content of his writing. What he arrived at was, as he says, a 'project that is at odds with the assertive and individualistic urges of colonialism. ${ }^{41}$

36 Wells, 'Living in Tin', 37-40.

37 Noel King, 'My Life Without Steve: Postmodernism, Fictocriticism and the Paraliterary',

Southern Review: Communication, Politics \& Culture, 27, no. 3 (1994): 261-75.

38 Ibid.

39 Ross Gibson, 26 Views of the Starburst World: William Dawes at the Sydney Cove, 1788-1791

(Perth: University of Western Australia Press, 2012), vii.

40 Ibid., 18.

41 Ibid. 
In my creative work I have also used a compositional approach: a blend of archival research, biography, geography, autoethnography, Indigenous and settler-colonial studies, and poetry along with a lyrical writing style. Central Australian intercultural history is explored from a range of viewpoints. It is also inherent in structural aspects of my story-telling including the variety of linguistic registers present; the hybridisation of genre; the discontinuous narrative, reflective of that character of memory; and a disruption of the linearity and coherence that we have been taught to expect from texts focused on information rather than knowledge. ${ }^{42}$

There are many ways that the interplay between theory and narrative can be presented in fictocritical works. To meet my aim of creating a work that would be accessible and appealing to the general reading public, I embedded the theory in the narrative, demonstrating rather than explicitly discussing scholarly theory. For example, the relationship between Ida Standley and Topsy Smith is, as far as I am concerned, one of the most fascinating and vital aspects of the Bungalow story. In his 1993 book I Can Picture the Old Home So Clearly, in which Tony Austin documents 'the response of the Commonwealth Government to the presence of young Aborigines of mixed descent in the Northern Territory in the period 1911 to 1939', the long association of Standley and Smith is described as 'nothing short of remarkable. ${ }^{43}$ It would indeed seem remarkable that they worked so closely together for those 15 years, in the most exceptional circumstances. At the same time, and with only a few specific details of their interactions to go by, it seems entirely possible that their relationship, defined to some large extent by their subject positions, was anything but remarkable. With minimal clues available about the kinds of interactions that might have gone on or not gone on within the confines of the Bungalow, engagement with both settler-colonial theory and the theories of intercultural relations can offer insights.

White women were always already in situations of power in relation to Aboriginal people, and on the frontier white women were cast as agents of civilisation. ${ }^{44}$ This certainly rings true for everything we know about the interactions between Ida, Topsy and the children of the Bungalow.

42 Rosslyn Prosser, 'Fragments of a Fictocritical Dictionary', Outskirts: Feminisms Along the Edge, 20 (2009), np; Dominique Hecq, 'Autofrictions: The Fictopoet, the Critic and the Teacher', Cultural Studies Review, 11, no. 2 (2005), 179-88.

43 Tony Austin, I Can Picture the Old Home So Clearly (Canberra: Aboriginal Studies Press, 1993), 2,61 .

44 Ann Curthoys, 'Identity Crisis: Colonialism, Nation, and Gender in Australian History', Gender \& History, 5, no. 2 (1993): 165-76; Alison Holland, 'The Campaign for Women Protectors: Gender, Race and Frontier between the Wars', Australian Feminist Studies, 16, no. 34 (1994): 27-42. 
Ida was in a position of colonial power and assumed the role of a maternal agent of civilisation. For example, as Topsy's granddaughter Christine told me, Mrs Standley told Topsy Smith off for showing honey ants to the kids. ${ }^{45}$ The children were, as Ida Standley reported to the Chief Protector in Darwin, 'most kind and obedient'. ${ }^{46}$ At the same time, when the authorities had left for the day and only the Indigenous inmates remained, I imagine they created a different space for themselves. Perhaps they spoke to each other in Arrernte. It is the language, as Christine said, that Topsy and her children preferred to speak into their senior years despite Arabana being the language of their ancestors. ${ }^{47}$ Whatever the lingua franca, it seems reasonable to surmise that the Indigenous epistemologies and ontologies - which the Bungalow residents brought to that place and were inherent in who they were-would have become more overt when the authorities were not around.

I have woven these theoretical considerations with the limited amount of historical evidence available on the relationship between the two women, into speculative pieces such as the following. Throughout my creative work, speculative works are denoted by their presentation in italics:

Mrs Standley reprimanded Topsy Smith for showing honey ants to Maggie.

Topsy! Don't be showing honey ants to Maggie. We are trying to discourage any interest in those heinous blackfella ways.

Heinous? Honey-ants? Topsy thought to herself. Honey ants are like bush tucker royalty. You don't know what you're missing, honey.

But to Ida she replied, 'Yes Mrs Standley,' and resolved to keep honey ants out of the public gaze.

Topsy used a scrubbing brush on the kids each morning with Ida Standley looking on.

Never mind his goosebumps and wailing and those patches of raw skin. Have you done behind his ears?

Yes Mrs. Standley. No Mrs. Standley.

Oh, I don't know for sure. My bias shines through. ${ }^{48}$

45 Christine Donnellan, personal communication, Alice Springs, 2019.

46 Austin, I Can Picture the Old Home, 62.

47 Christine Donnellan, personal communication, Alice Springs, 2019.

48 Wells, 'Living in Tin', 200. 


\section{Autohistory}

Writing yourself into the story as researcher and narrator (as exemplified in my last line above) is a technique deployed by various authors including Anna Funder in her work of creative non-fiction Stasiland (2002), and Laurence Binet in $H H h H$ (2013), which explores the story of Reinhard(t) Heydrich, the 'Hangman of Prague' and architect of the Final Solution during World War II. ${ }^{49}$ Binet writes himself into the story in several ways. One is by placing himself where the events occurred some 60 years earlier, seeking out material evidence, and sharing that embodied experience with the reader:

On Resslova Street-on the right-hand side as you go downthere is a church. And in the church's wall is a basement window bordered by stone where you can see various bullet marks and a plaque mentioning Gabčík and Kubiš—and Heydrich, whose name is now forever linked with theirs. I had passed this basement window dozens of times without noticing either the bullet marks or the plaque. But one day I stopped and read the words-and realized I had found the church where the parachutists took refuge after the assassination attempt.

I came back with Aurelie at a time when the church was open, and we were able to visit the crypt.

In the crypt, there was everything. ${ }^{50}$

There, in the physicality of that crypt and based on all the research he had done, Binet stood 60 years later, reimagining the events. Through describing it in his historical narrative, Binet lays bare the historical, philosophical truth, as expressed by Michaels in his discussion of $\mathrm{HHhH}$, that 'there is no such thing as knowing how things really happened and that all history is in some epistemically significant sense imagined by the historian'. ${ }^{51}$

49 Anna Funder, Stasiland: Stories from Behind the Berlin Wall (Melbourne: Text Publishing, 2002); Laurent Binet, $H H h H$ (London: Vintage Books, 2013).

50 Binet, $H H h H$, end of Chapter 5.

51 Watler Benn Michaels, 'Forgetting Auschwitz: Jonathan Littell and the Death of a Beautiful Woman', American Literary History, 25, no. 4 (2013): 915-30. 
This experience of Binet's is resonant of my own embodied research experience. I went to Alice Springs after a significant time away and travelled out to Jay Creek, to where the Bungalow had been relocated in the summer of 1928 to 1929 . There I spent time searching for material clues, feeling myself back into the bygone time and taking notes that informed the final section of my writing, 'Jay Creek':

At Jay Creek time co-mingles. There's the ancient past held tightly in the landscape and then the white tin church of the frontier. There's the busted-down Besser brick and the odd disposable nappy and flattened VB can that suggest an element of passing traffic. Where ancient rock meets disposable nappies; where missionary worship meets a postmodern author; where birds continue to sing the pretty tunes they composed before humans were invented. At Jay Creek, and across Central Australia, the past and present swirl together, challenging any notion of chronology. ${ }^{52}$

This autohistoric technique connects the past with the present. It also strips away the notion of one authoritative story, thus challenging the idea of objectivity in history. As English language scholar Christine Berberich explains:

postmodern thought tries to show up the fallacy of 'one' universal truth, of the 'one' grand narrative ... to each 'fact' there is a multitude of interpretations; and, additionally, each fact is always and inevitably given a meaning by the very person who selects or presents it. ${ }^{53}$

In this autohistoric approach the research 'data' is presented along with the experiences and reactions of the researcher as they access that data. It also dispenses with the notion of historic accounts as chronological. These are all elements I have striven for in my own work. 


\section{Autoethnography}

I have written myself into the story in two ways. One is through sharing experiences of the research journey, as discussed above. The other is autoethnographic. I have spent nearly three decades living in Alice Springs and broader Central Australia, experiencing and thinking through issues of racism, whiteness, oppression and intercultural relations. I have lived, learnt and felt the stories of the history of the place. I also lived in Central Australia as a woman of white privilege who has sometimes, inadvertently, supported the colonial project.

When I started to write the story of the Bungalow, I started to appear in it and, upon interrogation, my presence made sense. A 'characteristic that binds all autoethnographic work is the use of personal experience to examine or critique cultural experience'. ${ }^{54}$ If I had included stories of my own experience but not interrogated the nuances of those experiences in light of general cultural phenomena, then that writing would be autobiographical.

Another characteristic of autoethnographic writing consistent with my own is that 'autoethnographic texts demonstrate knowledge of past research on a topic and seek to contribute to this research. The knowledge of and reference to past research may be explicit or implicit'. ${ }^{55}$ Throughout my writing, the historic and cultural information that is expressed comes partly from the research I have conducted during the course of this project and partly from incidental research I conducted over years spent living in Central Australia.

In an autoethnographic sense, I appear in my work as a person who is giving her own personal perspective on the history and society of Central Australia from an informed outsider's perspective. I am informed because I have been immersed in Central Australian culture and society and am deeply affected by the social and cultural forces at play. I am an outsider because I did not experience this history first-hand, nor am I a First Nations person who suffers from the racist and discriminatory policies and practices that come with the colonial project. At the same time, you

54 Stacey Holman Jones, Tony E. Adams and Carolyn Ellis, 'Introduction: Coming to Know Autoethnography as More than a Method', in Handbook of Autoethnography, ed. Stacey Holman Jones, Tony E. Adams and Carolyn Ellis (Routledge: New York, 2013), 22.

55 Ibid., 23. 
cannot live in Central Australia, or Australia more broadly, without being affected by those policies and practices. We are all affected by the brutal and unresolved history of Australia whether we know it, or like it, or not.

\section{Conclusion}

I set out to research and write a story of the Bungalow Alice Springs, 1914-1929. The story seemed foundational to the society of Alice Springs, where I had lived for many years, and appeared to contain so many elements that are still of central concern to the town and region, a century later. My research was underpinned by an ethical awareness of my own subject position and the decolonised, feminist approach I favour in both the research and writing of Australian history. Engagement with primary sources provided me with historic data as well as insights into how the raw material of history is already biased. Engagement with secondary sources provided me with further historical details as well as insights into possible attitudes and atmospherics of the time. It also highlighted the subjective nature of works of history, even, or perhaps especially, those that attempt to pass themselves off as the most factual and objective.

In my work of history, I have combined writing of a more traditional historiographic nature with that based on informed imagination. One of the key features and findings of my project is the way these two styles can be merged, in a work of creative non-fiction, to give voice to those who have traditionally been silenced and develop a rich, nuanced and politically powerful site of historical investigation and encounter. 
This text is taken from Lilith: A Feminist History Journal: Number 27, published 2021 by ANU Press, The Australian National University,

Canberra, Australia.

doi.org/10.22459/LFHJ.27.04 